\title{
Stimulation of erythropoietin secretion by continuous subcutaneous infusion of recombinant human GH in anemic patients with chronic renal failure
}

\author{
Motoi Sohmiya, Kimiko Ishikawa and Yuzuru Kato \\ First Division, Department of Medicine, Shimane Medical University, Izumo, Japan \\ (Correspondence should be addressed to M Sohmiya, First Division, Department of Medicine, Shimane Medical University, Izumo 693, Japan)
}

\begin{abstract}
We have investigated the effect of human GH on erythropoietin (EPO) secretion in eight anemic patients with chronic renal failure (CRF) (three males and five females, aged from 46 to 83 years). Recombinant human GH was infused subcutaneously at a flow rate of $2 \mu \mathrm{g} / \mathrm{kg}$ body weight per $0.1 \mathrm{ml} / \mathrm{h}$ for $72 \mathrm{~h}$ using a portable infusion pump. Blood samples were obtained immediately before and 2, 4, 6, 12, $24,36,48,60,72,84,96,108,120$ and $168 \mathrm{~h}$ after the start of GH infusion. Storage urine samples were obtained before and 24,48 and $72 \mathrm{~h}$ after the start of the infusion. The mean ( \pm s.E.M.) basal plasma GH levels increased from $1.9 \pm 0.3$ to $18.8 \pm 0.7 \mu \mathrm{g} / \mathrm{l}$ during the GH infusion. Plasma IGF-I levels increased $12 \mathrm{~h}$ after the start of GH treatment and the mean peak values of $403.6 \pm 38.5 \mu \mathrm{g} / \mathrm{l}$ were obtained at $72 \mathrm{~h}$. Plasma EPO levels increased $6 \mathrm{~h}$ after the start of GH infusion, and the peak values of $38.4 \pm 11.6 \mathrm{IU} / \mathrm{l}$ were obtained at $96 \mathrm{~h}(P<0.05$ vs basal values $24.5 \pm 7.2 \mathrm{IU} / \mathrm{l})$. Reticulocyte counts increased from $28.7 \pm 5.2 \times 10^{3} / \mu \mathrm{l}$ to $40.3 \pm 8.0 \times 10^{3} / \mu \mathrm{l}$ at $108 \mathrm{~h}, 43.6 \pm 9.2 \times 10^{3} / \mu \mathrm{l}$ at $120 \mathrm{~h}$ and $41.7 \pm 7.7 \times 10^{3} / \mu \mathrm{l}$ at $160 \mathrm{~h}(P<0.05)$. Serum urea nitrogen decreased at $72 \mathrm{~h}(P<0.05)$, whereas there was no significant change in urinary excretion of nitrogen. Hemoglobin levels were not significantly changed throughout the experimental period. These findings indicate that human GH has a stimulating effect on EPO secretion in anemic patients with CRF.
\end{abstract}

European Journal of Endocrinology 138 302-306

\section{Introduction}

Erythropoiesis is mainly regulated by erythropoietin (EPO), a glycoprotein with a molecular mass of $34000 \mathrm{Da}$, and hypoxia-induced erythropoiesis is mediated by an increase of EPO secretion (1). EPO is mainly produced in the kidney, but partly in the liver in the rat $(2-5)$. Anemia accompanied by chronic renal failure (CRF) is characterized by relatively blunted EPO secretion from the kidney (6).

The endocrine system also plays a role in the regulation of erythropoiesis $(7,8)$. Hypopituitarism is often accompanied by normochromic and normocytic anemia, and erythroid hypoplasia of the bone marrow, resulting in normochromic and normocytic anemia, which is partly corrected by replacement with growth hormone (GH) (9). It was considered that $\mathrm{GH}$ had no direct effect on hemopoiesis, but rather influenced the bone marrow function indirectly through improved general metabolism (10, 11). It has been recently reported that $\mathrm{GH}$ has a direct stimulating effect on hematopoietic cells in vitro (12). It has also been reported that GH stimulates erythropoiesis via insulin-like growth factor-I (IGF-I), a $\mathrm{GH}$ dependent growth factor (13). It remains to be elucidated, however, whether GH stimulates EPO secretion in the human.

In the present study, we investigated the effect of human GH on plasma EPO levels in anemic patients with CRF.

\section{Materials and methods}

\section{Subjects}

Eight patients with CRF, three males and five females, were studied. The mean ( \pm s.E.M.) age was $65.9 \pm 5.2$ years (range 46-83 years). They included six patients with diabetic nephropathy, one patient with chronic nephritis and one with renovascular renal failure. Body mass index was $20.7 \pm 1.6 \mathrm{~kg} / \mathrm{m}^{2}$. All the patients had high serum creatinine $(\mathrm{Cr})$ levels of $265.2 \pm 56.3 \mu \mathrm{mol} / \mathrm{l}$ (normal range: 61.9 to $106.1 \mu \mathrm{mol} / \mathrm{l}$ ) and high serum urea nitrogen (UN) levels of $15.7 \pm 7.8 \mathrm{mmol} / \mathrm{l}$ (normal range: 1.8 to $7.1 \mathrm{mmol} / \mathrm{l})$. All the patients had low hemoglobin $(\mathrm{Hb})$ levels of $8.4 \pm 0.8 \mathrm{~g} / \mathrm{dl}$ (normal range: 13.0 to $16.0 \mathrm{~g} / \mathrm{dl}$ ) and relatively low plasma EPO levels of $24.3 \pm 7.3 \mathrm{IU} / \mathrm{l}$ (normal range in a control group without anemia: 7.9 to $30.3 \mathrm{IU} / \mathrm{l})$. Plasma IGF-I 
levels were $184.3 \pm 17.4 \mu \mathrm{g} / \mathrm{l}$ (normal range: 124.0 to $197.4 \mu \mathrm{g} / \mathrm{l}$ (male) and 80.9 to $212.7 \mu \mathrm{g} / \mathrm{l}$ (female)). Serum tri-iodothyronine, thyroxine $\left(\mathrm{T}_{4}\right)$, free $\mathrm{T}_{4}$ and thyroid-stimulating hormone (TSH) levels were 117.2 \pm $8.5 \mathrm{ng} / \mathrm{dl}$ (normal range: 90 to $195 \mathrm{ng} / \mathrm{dl}), 7.6 \pm 0.4 \mu \mathrm{g} / \mathrm{dl}$ (normal range: 5.4 to $13.5 \mu \mathrm{g} / \mathrm{dl}$ ), $1.1 \pm 0.1 \mathrm{ng} / \mathrm{dl}$ (normal range: 0.9 to $1.9 \mathrm{ng} / \mathrm{dl}$ ) and $2.81 \pm 0.76 \mathrm{mU} / \mathrm{l}$ (normal range: 0.32 to $3.70 \mathrm{mU} / \mathrm{l}$ ) respectively. Serum cortisol levels were $12.0 \pm 1.3 \mu \mathrm{g} / \mathrm{dl}$ (normal range: 2 to $18 \mu \mathrm{g} / \mathrm{dl}$ ). All patients were maintained on a diet containing $30 \mathrm{kcal} / \mathrm{kg}$ body weight (BW) per day including $1.0 \mathrm{~g} /$ $\mathrm{kg}$ BW of protein during the admission. BW and blood pressure did not change during the study. Written informed consent was obtained from all subjects.

\section{Protocol}

After overnight fasting, an indwelling catheter was placed into a cubital vein for blood sampling. The $22 \mathrm{kDa}$ form of recombinant human GH (Sumitomo Co., Tokyo, Japan) was dissolved in $0.9 \%$ saline containing $0.3 \%$ human albumin and subcutaneously infused into the abdominal wall for $72 \mathrm{~h}$ at a flow rate of $2 \mu \mathrm{g} / \mathrm{kg} \mathrm{BW}$ per $100 \mu \mathrm{l} / \mathrm{h}$ using a portable syringe infusion pump (SP-3HQ, Nipro Co., Osaka, Japan). Blood samples were obtained immediately before and 2, 4, 6, 12, 24, 36, 48, $60,72,84,96,108,120$ and $168 \mathrm{~h}$ after the start of $\mathrm{GH}$ infusion. Plasma samples were kept frozen at $-20^{\circ} \mathrm{C}$ until assayed. The storage urine samples were obtained before and 24, 48 and $72 \mathrm{~h}$ after the start of $\mathrm{GH}$ infusion. Urine samples were kept at $-20{ }^{\circ} \mathrm{C}$ until assayed. Plasma GH, EPO, IGF-I, Cr, serum UN, Hb concentration and reticulocyte counts (RC) as well as urine $\mathrm{Cr}$ and nitrogen were determined.

\section{Assays}

Plasma GH levels were measured by a highly sensitive enzyme immunoassay in duplicate as previously described (14-16). The minimum detectable quantity was $3 \mathrm{ng} / \mathrm{l}$ using $20 \mu \mathrm{l}$ plasma. The intra- and interassay coefficients of variation were $6.0 \%$ and $9.8 \%$ respectively. Plasma EPO levels were determined by a commercially available RIA kit (Recombigen EPO, Japan DPC Co., Chiba, Japan) as described previously (17). The minimum detectable quantity was $5 \mathrm{IU} / \mathrm{l}$. Plasma IGF-I levels were measured by specific RIA after acidethanol extraction as previously described (18). Plasma and urinary $\mathrm{Cr}$ were measured by an autoanalyzer (TBA50S, Toshiba, Tokyo, Japan). Urinary nitrogen was measured by the decompression chemiluminescence method. Serum UN, $\mathrm{Hb}$ and RC were determined by conventional methods.

\section{Statistical analysis}

Statistical differences were evaluated by analysis of variance in combination with the paired $t$-test. A $P$ value less than $0 \cdot 05$ was considered significant.

\section{Results}

As shown in the upper panel of Fig. 1, mean ( \pm s.E.M.) plasma GH levels increased from $1.9 \pm 0.3$ to $18.8 \pm$ $0.7 \mu \mathrm{g} / \mathrm{l}$ during the subcutaneous infusion of human $\mathrm{GH}$. At $12 \mathrm{~h}$ after the end of $\mathrm{GH}$ infusion, plasma $\mathrm{GH}$ returned to the basal level $(1.6 \pm 0.2 \mu \mathrm{g} / \mathrm{l})$. As shown in the lower panel of Fig. 1, mean plasma IGF-I levels increased at $12 \mathrm{~h}$ after the start of $\mathrm{GH}$ infusion $(211.5 \pm 15.0 \mu \mathrm{g} / \mathrm{l}$ vs basal value $184.4 \pm 23.3 \mu \mathrm{g} / \mathrm{l}$, $P<0.01)$. The peak value of plasma IGF-I was obtained at $72 \mathrm{~h}$ after the start of $\mathrm{GH}$ infusion $(408.4 \pm 43.4 \mu \mathrm{g} / \mathrm{l}$, $P<0.001$ vs basal value). After the end of GH infusion, plasma IGF-I levels gradually decreased but were still greater than the basal level at $168 \mathrm{~h}(234.3 \pm 45.4 \mu \mathrm{g} / \mathrm{l}$,
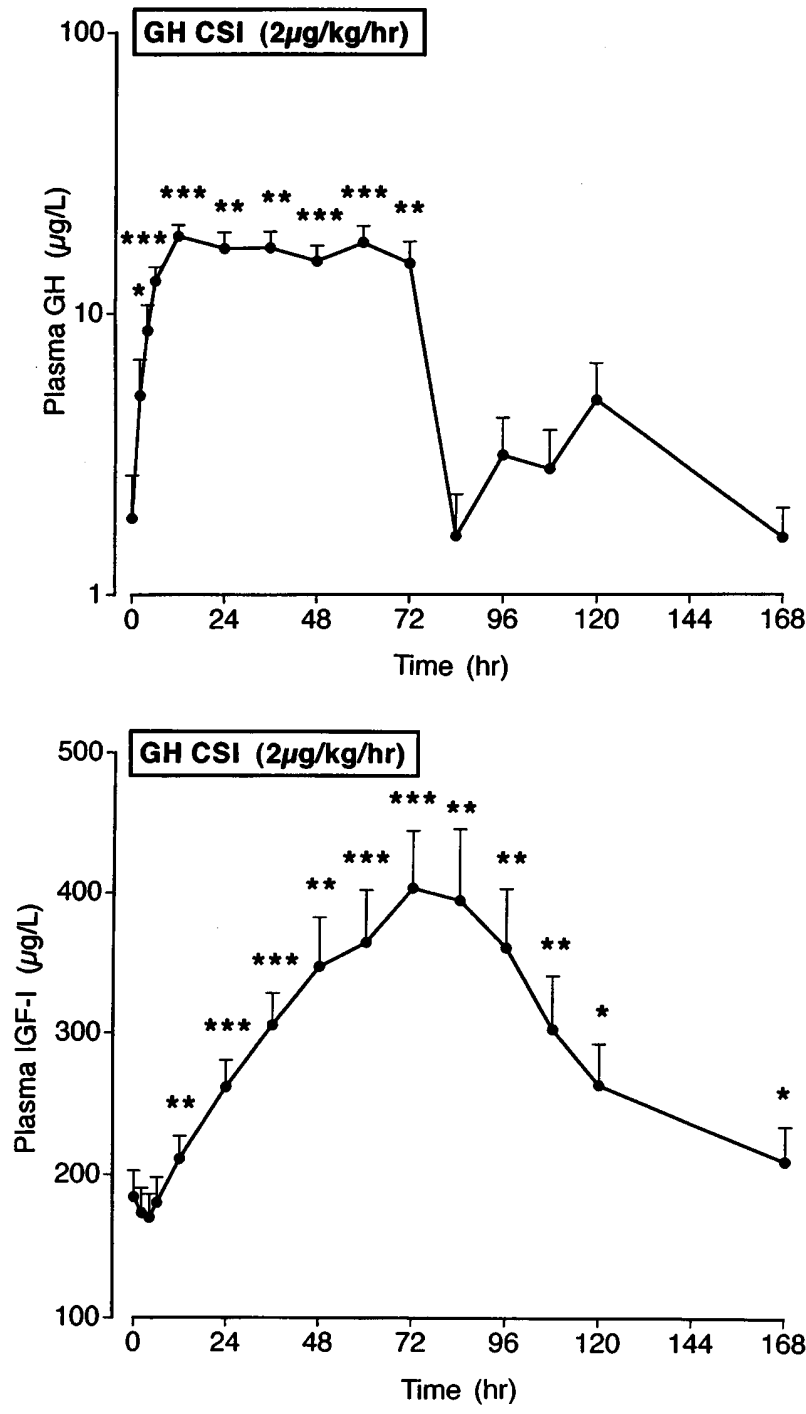

Figure 1 Plasma GH and IGF-I levels after GH constant subcutaneous infusion (CSI) in eight anemic patients with CRF. GH was infused at $2 \mu \mathrm{g} / \mathrm{kg} \mathrm{BW}$ per h for $72 \mathrm{~h}$. Data are means \pm S.E.M. ${ }^{\star} P<0.05,{ }^{\star \star} P<0.01$ and ${ }^{\star \star \star} P<0.005$ vs $0 \mathrm{~h}$. 
$P<0.05)$. Plasma EPO levels were considerably elevated at $6 \mathrm{~h}$ after the start of $\mathrm{GH}$ infusion $(27.5 \pm 7.5 \mathrm{IU} / \mathrm{l}$ vs basal level $24.5 \pm 7.2 \mathrm{IU} / \mathrm{l}, P<0.01$ ) and the peak value of plasma EPO was obtained at $96 \mathrm{~h}$ after the end of $\mathrm{GH}$ infusion (38.4 $\pm 11.6 \mathrm{IU} / \mathrm{l}, P<0.05 \mathrm{vs}$ basal level) (Fig. 2 , upper panel). Plasma EPO levels remained increased at $168 \mathrm{~h}(33.4 \pm 8.1 \mathrm{IU} / \mathrm{l}, \quad P<0.05$ vs basal level). As shown in the lower panel of Fig. 2, RC increased at 108,120 and $168 \mathrm{~h}$ after the start of $\mathrm{GH}$ infusion $\left(40.3 \pm 8.0 \times 10^{3} / \mu \mathrm{l}, 43.6 \pm 9.2 \times 10^{3} / \mu \mathrm{l}\right.$ and $41.7 \pm$ $7.7 \times 10^{3} / \mu$ l respectively, $P<0.05$ vs basal level $28.7 \pm$ $\left.5.2 \times 10^{3} / \mu \mathrm{l}\right)$. However, there was no significant change in Hb levels. Mean serum UN levels decreased at $72 \mathrm{~h}$ after the start of $\mathrm{GH}$ infusion $(5.47 \pm 1.00 \mathrm{mmol} / \mathrm{l}$ vs basal level $6.06 \pm 1.04 \mathrm{mmol} / \mathrm{l}, P<0.05)$. Urinary nitrogen excretion was not significantly decreased during $72 \mathrm{~h}$ (basal level $582.2 \pm 57.8 \mathrm{mmol} /$ day, $537.9 \pm$ $107.3 \mathrm{mmol} /$ day at $72 \mathrm{~h}$ ). There was no change in serum $\mathrm{Cr}$ levels and $24 \mathrm{~h} \mathrm{Cr}$ clearance during the $\mathrm{GH}$ infusion.
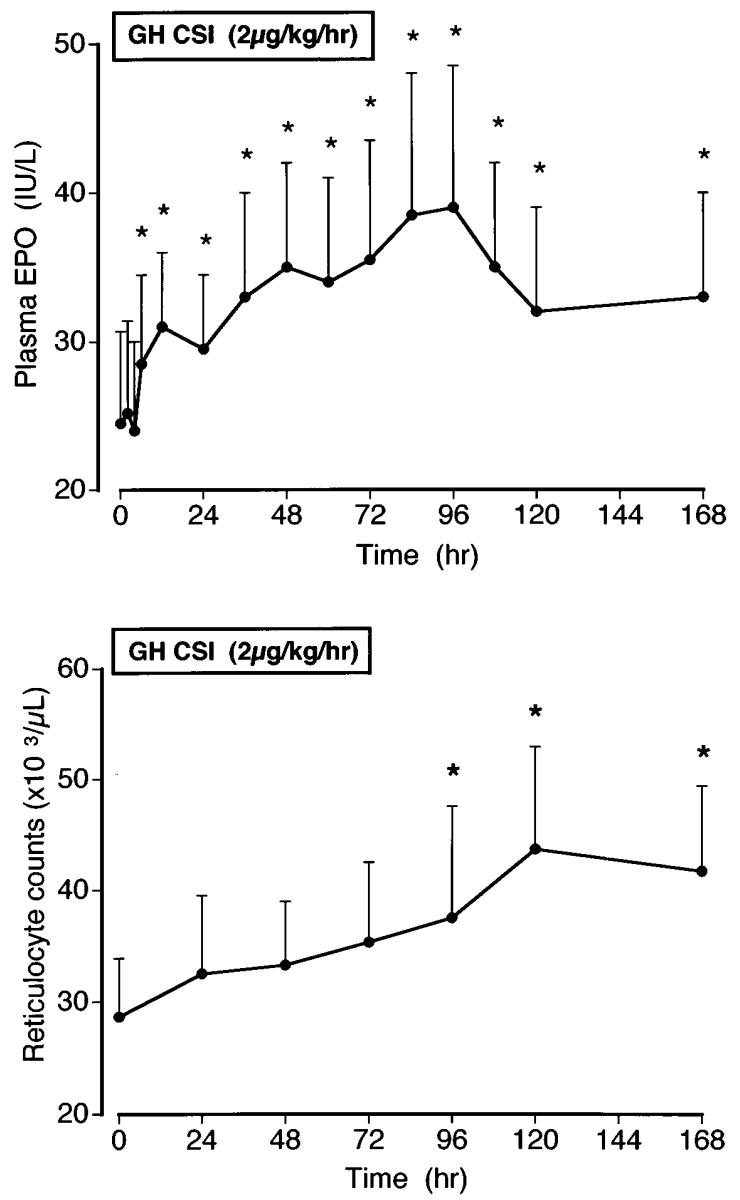

Figure 2 Plasma EPO levels and RC after GH constant subcutaneous infusion (CSI) in eight anemic patients with CRF. Data are means \pm S.E.M. ${ }^{*} P<0.05$ vs $0 \mathrm{~h}$.

\section{Discussion}

The relationship between the endocrine system and hemopoiesis has been known for nearly half a century (7, $10,11,19,20)$. Hypopituitarism is often accompanied by normochromic and normocytic anemia. The appropriate replacement therapy with glucocorticoid and $\mathrm{T}_{4}$ increases $\mathrm{Hb}$ concentration, which does not reach the normal range in some cases. Hypoplastic bone marrow is restored by GH treatment, but not by adrenocorticotropic hormone, follicle-stimulating hormone, luteinizing hormone and $\operatorname{TSH}(7,21)$. Androgen and thyroid hormone are known to stimulate erythropoiesis (22).

EPO is the major humoral regulator of erythropoiesis, which is mainly secreted from the endothelium and interstitial fibroblasts of renal tubules, and partly secreted from the liver in the rat $(2,4,5)$. EPO secretion is mainly controlled by oxygen pressure (23). Hypoxia rapidly stimulates EPO secretion and EPO-encoding mRNA appears in the kidney and the liver within $1 \mathrm{~h}$ of inducing anemia in mice and rats $(3,24)$.

There have been a few reports on endocrinological regulation of EPO secretion. It was previously reported that $\mathrm{GH}$ treatment increased Hb levels and urine excretion of EPO in patients with hypopituitarism, in which EPO activity was determined by bioassay using polycythemic mice (20). However, the effect of GH treatment on plasma EPO levels remained to be elucidated.

In the present study, we found that plasma EPO levels increased within $6 \mathrm{~h}$ of the start of $\mathrm{GH}$ infusion in anemic patients with CRF. The rapid increase in plasma EPO suggests a direct stimulating action of GH on EPO secretion. GH stimulated erythropoiesis in nephrectomized and hypophysectomized rats (25) and in rat bone marrow perfused with GH (26). Furthermore, GH directly stimulated the proliferation of erythroid progenitor cells in vitro (12). Kotzmann et al. (27) recently reported that erythroid and myeloid progenitor precursor cells increased after $\mathrm{GH}$ replacement in adult patients with GH deficiency whereas peripheral red blood cells, reticulocytes and EPO remained almost unchanged. IGF-I also has a stimulating activity on erythropoiesis in vitro (28) and in vivo (29). Merchav et al. (13) indicated that IGF-I plays a role as a mediator of erythropoiesis induced by $\mathrm{GH}$ since the effect was attenuated by monoclonal antibody against IGF-I. It has also been reported that IGF-I has stimulatory effects on EPO secretion in patients with insulin resistance (30). In the present study, plasma EPO levels increased earlier than did those of plasma IGF-I, which was detected at $12 \mathrm{~h}$ after the start of $\mathrm{GH}$ infusion, indicating that $\mathrm{GH}$ has a directly stimulating effect on EPO secretion.

The stimulating effect of GH on erythropoiesis could be explained, at least partly, by anabolic action rather than a direct effect. The anabolic effect of GH induces an increase in metabolic activity and necessity for oxygen transport to peripheral tissue, resulting in an increase of oxygen transportation and $\mathrm{Hb}$ levels (9). Erythropoiesis 
was really stimulated by androgen $(19,22)$. Malgor \& Fisher (31) reported that androgen stimulated EPO secretion from isolated and perfused dog kidney. These findings indicate that the stimulating effect of androgen on erythropoiesis is not simply due to anabolic effects. Subcutaneous injection of GH produced nitrogen retention in catabolic subjects at a dose of $100 \mu \mathrm{g} / \mathrm{kg}$ per day (32). On the other hand, it was reported that $66 \mu \mathrm{g} / \mathrm{kg}$ per day of GH did not show any anabolic effects in catabolic status (33). We administered $\mathrm{GH}$ as a continuous subcutaneous injection at the lower dose of $2 \mu \mathrm{g} / \mathrm{kg}$ per $\mathrm{h}$, which is equivalent to $48 \mu \mathrm{g} / \mathrm{kg}$ per day. Serum UN levels slightly decreased at $72 \mathrm{~h}$, whereas urinary nitrogen excretion was not significantly decreased, indicating that anabolic effects were not evident during the continuous subcutaneous infusion of $\mathrm{GH}$ at this dose for $72 \mathrm{~h}$.

We found that EPO secretion was stimulated by $\mathrm{GH}$ administration in these patients. However, it remains to be elucidated where the EPO originated from in these subjects. The liver is the major site of EPO production in the ovine fetus, whereas the kidney plays a major role in EPO production in adult sheep (34). In the neonatal rat, EPO was found to originate from the liver rather than the kidney, and hypoxia induced EPO production in the kidney and the liver (35). Although there is no report suggesting that EPO is secreted from the liver in the adult human, it may be possible that EPO is partly produced in the liver when the kidney function is impaired in patients with CRF. As IGF-I is mainly produced in the liver, EPO secretion from the kidney might be locally stimulated by IGF-I; as a result the prolonged EPO secretion after the discontinuation of $\mathrm{GH}$ might be partly mediated by IGF-I stimulated by GH infusion.

In summary, constant subcutaneous infusion of recombinant human $\mathrm{GH}$ for $72 \mathrm{~h}$ raised plasma EPO levels and $\mathrm{RC}$ in anemic patients with CRF. An increase of plasma EPO was obtained earlier than an increase of plasma IGF-I, suggesting that $\mathrm{GH}$ has a directly stimulating effect on EPO secretion. Although $\mathrm{Hb}$ concentrations were not changed in the present study, longer administration of GH needs to be studied for its effect on anemia in these patients with renal disease. However, as GH administration for a longer term might induce hypertension and hyperglycemia in aged subjects (36), careful observation is required to avoid secondary side effects.

\section{Acknowledgements}

This work was supported in part by grants from the Ministry of Education, Science and Culture, Japan, the Ministry of Health and Welfare, Japan, and the Growth Foundation, Japan. We thank Japan DPC Co., Chiba, for supplying the Recombigen EPO RIA kit. We are indebted to Mrs Akiko Kawakami for secretarial assistance.

\section{References}

1 Goldberg MA, Imagawa S, Dunning PS \& Bunn HF. Oxygen sensing and erythropoietin gene regulation. Contributions to Nephrology 198970 39-56.

2 Kurtz A, Eckardt KU, Neumann R, Kaissling B, Le Hir M \& Bauer C. Site of erythropoietin formation. Contributions to Nephrology 1989 76 14-23.

3 Bondurant MC \& Koury MJ. Anemia induces accumulation of erythropoietin mRNA in the kidney and liver. Molecular and Cellular Biology 19866 2731-2733.

4 Koury ST, Bondurant MC \& Koury MJ. Localization of erythropoietin synthesizing cells in murine kidneys by in situ hybridization. Blood 198871 524-527.

5 Koury ST, Koury MJ, Bondurant MC, Caro J \& Graber SE. Quantitation of erythropoietin-producing cells in kidneys of mice by in situ hybridization: correlation with hematocrit, renal erythropoietin mRNA, and serum erythropoietin concentration. Blood 198974 645-651.

6 Eschbach JW \& Adamson JW. Anemia of end-stage renal disease. Kidney International $1985281-5$.

7 Nagy E \& Berczi I. Pituitary dependence of bone marrow function. British Journal of Haematology 198971 457-462.

8 Peschle C, Rappaport IA, Magli MC, Marone G, Lettieri F, Cillo C et al. Role of the hypophysis in erythropoietin production during hypoxia. Blood 197851 1117-1124.

9 Jepson JH \& McGarry EE. Hemopoiesis in pituitary dwarfs treated with human growth hormone and testosterone. Blood 197239 238-248.

10 Gordon AS. Endocrine influences upon the formed elements of blood and blood forming organs. Recent Progress in Hormone Research $195410339-394$.

11 Crafts SG \& Meineke HA. The anemia of hypophysectomized animals. Annals of the New York Academy of Sciences 195977 501-517.

12 Golde DW, Bersch N \& Li CH. Growth hormone: species-specific stimulation of erythropoiesis in vitro. Science $19771961112-$ 1113.

13 Merchav S, Tatarsky I \& Hochberg Z. Enhancement of erythropoiesis in vitro by human growth hormone is mediated by insulinlike growth factor I. British Journal of Haematology 198870 267271 .

14 Hashida S, Ishikawa E, Nakagawa K, Ohtaki S, Ichioka T \& Nakajima K. Demonstration of human growth hormone in normal urine by a highly specific and sensitive enzyme immunoassay. Analytical Letter 198518 1623-1634.

15 Sohmiya M \& Kato Y. Renal clearance, metabolic clearance rate, and half-life of human growth hormone in young and aged subjects. Journal of Clinical Endocrinology and Metabolism 199275 1487-1490

16 Sohmiya M, Yamamoto H \& Kato Y. Age- and sex-related changes in urinary growth hormone $(\mathrm{GH})$ levels in normal adults. Biomedical Research $19934227-238$.

17 Kato Y, Takagi C, Tanaka J, Masaki Y \& Furuya H. Effect of daily subcutaneous administration of recombinant erythropoietin on chronic anemia in rheumatoid arthritis. Internal Medicine 1994 33 193-197.

18 Yamamoto H, Sohmiya M, Oka N \& Kato Y. Effects of aging and sex on plasma insulin-like growth factor I (IGF-I) levels in normal adults. Acta Endocrinologica 1991124 497-500.

19 Kennedy BJ \& Gilbertsen AS. Increased erythropoiesis induced by androgenic hormone therapy. New England Journal of Medicine $1957256719-726$.

20 Jepson JH, McGarry EE \& Lowenstein LL. Erythropoietin excretion in a hypopituitary patient. Effects of testosterone and vasopressin. Archives of Internal Medicine 1968122 265-270.

21 Jepson JH \& Lowenstein L. Effect of prolactin on erythropoiesis in the mouse. Blood 196424 726-738.

22 Alexanian R. Erythropoietin and erythropoiesis in anemic man following androgen. Blood 196933 564-572. 
23 Eckardt K, Kurtz A, ScholzH \& Bauer C. Regulation of erythropoietin formation in vivo. Contributions to Nephrology 198976 33-38.

24 Beru N, McDonald J, Lacombe C \& Goldwasser E. Expression of the erythropoietin gene. Molecular and Cellular Biology 19866 2571-2575.

25 Fisher JW, Roh BL, Couch C \& Nightingale WO. Influence of cobalt, sheep erythropoietin and several hormones on erythropoiesis in bone marrows of isolated perfused hind limbs of dogs. Blood 196423 87-98.

26 Meineke HA \& Crafts RC. Further observations on the mechanism by which androgens and growth hormone influence erythropoiesis. Annals of the New York Academy of Sciences 1968 149 298-307.

27 Kotzmann H, Riedl M, Clodi M, Barnas U, Kaider A, Hocker P et al. The influence of growth hormone substitution therapy on erythroid and myeloid progenitor cells and on peripheral blood cells in adult patients with growth hormone deficiency. European Journal of Clinical Investigation 199626 1175-1181.

28 Claustres M, Chatelain P \& Sultan C. Insulin-like growth factor I stimulates human erythroid colony formation in vitro. Journal of Clinical Endocrinology and Metabolism 198765 78-82.

29 Kurtz A, Zapf J, Eckardt KU, Clemons G, Froesch ER \& Bauer C. Insulin-like growth factor I stimulates erythropoiesis in hypophysectomized rats. Proceedings of the National Academy of Sciences of the USA $1988857825-7829$.

30 Quin J, Miell J, Smith K, Gordon D, Strachan J, Dick JB et al. Effect of insulin-like growth factor-I therapy on erythropoietin concentrations in extreme insulin resistance. Diabetologia 1994 37439.

31 Malgor LA \& Fisher JW. Effects of testosterone on erythropoietin production in isolated perfused kidneys. American Journal of Physiology $19702181732-1736$.

32 Mulligan K, Grunfeld C, Hellerstein MK, Neese RA \& Schambelan M. Anabolic effects of recombinant human growth hormone in patients with wasting associated with human immunodeficiency virus infection. Journal of Clinical Endocrinology and Metabolism 199377 956-962.

33 Roth E, Valentini L, Semsroth M, Hölzenbein T, Winkler S, Blum WF et al. Resistance of nitrogen metabolism to growth hormone treatment in the early phase after injury of patients with multiple injuries. Journal of Trauma 199538 136-141.

34 Zanjani ED, Ascensao JL, McGlave PB, Banisadre M \& Ash RC. Studies of the liver to kidney switch of erythropoietin production. Journal of Clinical Investigation 198167 1183-1188.

35 Clemons GK, Fitzsimmons SL \& DeManincor D. Immunoreactive erythropoietin concentration in fetal and neonatal rats and the effects of hypoxia. Blood 198668 892-899.

36 Rudman D, Feller AG, Nagraj HS, Gergans GA, Lalitha PY, Goldberg AF et al. Effects of human growth hormone in men over 60 years old. New England Journal of Medicine 1990323 1-6.

Received 5 August 1997

Accepted 24 November 1997 